\title{
Profile of Basic Language Skills of Kindergarten Children and Implications for Guidance and Counselling
}

\author{
Euis Farida Zahra \\ UPI, J1. Dr. Setiabudhi No. 229, Bandung, Indonesia \\ Corresponding e-mail: euisfaridazahra@gmail.com
}

\begin{abstract}
Speaking is one of the basic skills possessed by each individual. In developing speaking skill, it will better if it is done since the children studying in kindergarten. But in fact, the speaking skill often gets a lot of obstacles during its development. Hence, this study aimed at describing the basic proficiency profile of the children the kindergarten and its implications towards Guidance and Counselling. The method used in this research is descriptive method in which samples of this research were kindergarten students, kindergarten teachers, and parents who send their children to one kindergarten in Bandung. The results show that the children have sufficient ability to be able to implement the basic language skills in listening, speaking, reading, and writing. The study also found a weakness of the kindergarten teachers who prefer teaching reading, writing, mathematics, and memorization to speaking. The implication in guidance and counselling program on children's development was to facilitate the children with variant methods to improve children's basic language skills. As for teachers, it is suggested to do self-development in order to enrich their knowledge and skills to help and support the development of the basic language skills for children.
\end{abstract}

Keywords: basic proficiency in kindergarten, guidance and counseling

\section{INTRODUCTION}

Speaking is one of language skills needed by everyone because it becomes a major communication tool. At the level of early childhood education, particularly kindergarten, language becomes the main tool for children to interact with their friends, teachers, and their environment. Otto, B (2015) clearly states that children in kindergarten age are able to master 1,500 vocabularies or more for communication. But in reality, sometimes learning activities in kindergarten are still lacking in accommodating the ability of children's language. Some indications appear in the weaknesses of language learning. The children only learn about reading, writing, and counting so that the teachers arrange the learning activities for children to master these three skills regardless of the diversity of children abilities and interests. In fact, Learning Activities Program in kindergarten is the unity of the whole program of learning activities. Reber (Agustin, 2012) claims that the terrors treatment/stimulation in children can affect children's learning such as the disruption of learning activities, psychological, and in some cases resulted in the loss of valuable potential in children.

Furthermore, the learning program in kindergarten expects the children to achieve certain progress in accordance with the future, so that they are ready continue their education to elementary school.

The realities that exist in several primary educators is that the students have been able to read. It can be seen from the way the teachers deliver a variety of subjects. For example, the teachers often say to see a particular page to read the explanation of the subject. The daily test and final test at the middle and end of semester are presented in written form. This clearly indicates that before registering into the first grade of elementary school, children are assumed that they have been able to read. Reading is 
one of the basic skills, besides writing and counting. Reading skill is very important because it can affect the reading and writing skills. Besides that, it also plays a role in the activities of counting. According to Havighurst (Ma'mun, 1994:49) one of the tasks in children's development aged 6-12 years is to develop the basic skills of reading, writing, and counting. It is also mentioned in the Basic Education Curriculum that for the early grades (Grades I - III) emphasizes on mastery of basic skills in the learning of reading, writing, and counting. Through reading, someone will be able to gain knowledge that cannot be obtained through ordinary experiences. Reading can help expanding children's thoughts and ideas as well as individual creativity in various fields.

Reading can be said to be a window of knowledge.

Some cases of children's learning difficulties are caused by a lack of the children's ability children in reading. If it does not get special guidance, it is feared they can be frustrated in learning a variety of subjects that. It can be more fatal that the children can have more complex effects when they have learning difficulties but they have to stay in class. Therefore, reading issue should be considered by educators since the early ages of children. Based on the problems, the research focuses on identifying the basic proficiency profile kindergarten children and their implications for guidance and counseling.

\section{METHOD}

\subsection{Method}

The method of the research is descriptive method because the research was intended to explain some events that occur in the present. This research aimed at obtaining empirical about basic proficiencies in children including listening, speaking, reading, and writing. Language learning activities in the classroom and the carrying capacity of the facilities and infrastructure became the concern as well. To gain these data, the authors conducted observation to investigate the language learning process, the interaction between teacher and kindergarten students, the language used, and to comprehend the interpretation of the world around them. Besides that, the author conducted documentary study. During the research, the authors conducted a "share" session when there were things that needed to be discussed. In this case, the respondents got some benefits.

\subsection{Subject}

The subjects of this research were the students of a kindergarten in Bandung. It was taken with the technique of "purposive sampling". In order to answer the research question, therefore the main subjects of this research are students, kindergarten teachers, and parents of students in kindergarten. The consideration to select students and kindergarten teacher as research subjects is based on the fact that the students and teachers are directly involved into the process of learning.

\subsection{Development of Instruments}

The data required in this research were revealed by using observation supported by interviews and supplemented by documentary studies. The use of observation techniques conducted to see the learning process performed by the teachers to help children developing the ability to speak and read. Interviews were conducted to teachers and principals who are meant to know the efforts made by teachers and principals in teaching their students.

\subsection{Data Analysis of Research}

In this research, the data analysis was performed based on the data type obtained during on the field. The observation and interviews were done based on the developed guidance. The process of analyzing data from observations and interviews conducted continuously during the study. The process of this research is that the data obtained is not going to be bias because of researcher's forgetfulness or the poor-administered data. With such an analysis process, an accurate results were obtained. In addition, this process analysis helped the study. If the data were considered incomplete, it could be quickly be equipped. The data from the analysis results were rechecked to the subject of research to prove that the obtained data was accurate.

\section{RESULT AND DISCUSSION}

The results showed that the children had enough proficiency in implementing the basic language skills i.e. listening, speaking, reading, and writing as illustrated in table. 
Table 1. Profile of Basic Skill Language of Kindergarten Children

\begin{tabular}{|c|c|c|c|c|c|c|c|}
\hline No & Subjects & Age & Sex & L & S & R & W \\
\hline 1 & AG & 5.9 & F & E & E & E & G \\
\hline 2 & MI & 5.8 & M & G & G & E & E \\
\hline 3 & NE & 5.6 & F & E & E & L & E \\
\hline 4 & HA & 5.7 & M & G & E & E & E \\
\hline 5 & KN & 5.10 & F & G & G & G & E \\
\hline 6 & VA & 5.11 & F & E & E & G & G \\
\hline 7 & AA & 5.9 & M & E & E & E & E \\
\hline 8 & MM & 5.7 & M & E & E & E & E \\
\hline 9 & QA & 5.7 & F & E & E & L & E \\
\hline 10 & GA & 5.6 & M & E & G & G & G \\
\hline 11 & DS & 5.5 & F & E & E & E & E \\
\hline 12 & RD & 5.6 & M & E & E & E & E \\
\hline
\end{tabular}

Note:

G: Good

E: Enough

L: Less

Basic language skills of children who became the subject of this study indicated a fairly positive dynamics. It means that everyone showed diversity in language ability, so the researchers assumed that they had the potential to develop their language skills optimal, as well as a capital to develop other aspects of development. Naturally, the children had shown proficiency in particular areas of reading and writing (Durken 1966; Clay 1972; Holdaway 1979; Bissex 1980; Yetta Goodman, 1985, 1986; Harste, Woodway, and Burke 1985; Dorke 1985; and Wells 1986). Teale and Sulzby (1986), in Fisher (1988: 8), has adopted the term "emergent literacy" (legibility appears) to describe the development of legibility at young children, especially before five or six years old when they began to read and write in conventional forms. Both of them summarized what was learned about the legibility appeared in the last two decades as follow: (1) the development of reading began long before children start formal learning; (2) the development of legibility was the right way to describe called reading readiness: that children developed as a writer/reader; (3) the legibility developed in the background of real life activities in order to "make things done"; (4) the children that were carried out cognitive work were critical in the development of legibility during the new-born until six years old; (5) the children learned a written language through active engagement with their world; (6) although the children's learning about the legibility could be described in terms of stages that generalized, children could break through these stages in different ways and different ages.

The experts agree that language establishment of in children was influenced by the factor of training and motivation (willing) to learn through the process of conditioning and reinforcement (Lefrancois, 1975 in Ma'mun, 1994: 72).

Furthermore, they also explain that although the content and the type of language learned by a man was different, but there was a pattern of developmental sequences that are universal in the process of language development started by palpating, speaking monologue (on her or objects toys), thirsting for names , avidly asking (what, why, how, etc.) that do not always have to be answered, making a simple sentence (one, two or three words), expressing language (to learn writing, reading and drawing starters).

Children aged 6-7 years old have the capacity to know and master, people already knew and mastered up to 2,500 words, even supposedly more. Basic proficiency in children covered four skills such as listening, speaking, reading and writing. It can be seen from the manifestation of their behaviour in dealing with other people. According to Halliday (1975), people learn language as an interactive process that occurs in a social context. Yetta Goodman (1985) reveals that our best judgment about what the children are learning is to watch and listen to them in a social context.

According to Chomsky (Rachmat, 1986: 283), every child is able to use a language for their innate knowledge (pre-existent knowledge) that have been genetically programmed into brains. He named this knowledge as LAD (Language Acquisition Device). It does not contain the word, meaning, or the idea, but it is only one system that allows humans to incorporate components of language. Although the outer shape language in the world (surface structure) is different, these languages have a common in the basic underlying structure. Chomsky called it linguistic universal. Children are equipped with this capability. They immediately know the relationship among the forms of their mother tongue with the forms contained in in the grammatical structure that presents on the head. The relationship causes the children naturally say the sentences in accordance with the rules of their language.

Nativism theory describes the children acquire knowledge about a specific language, when the language is heard evokes the innate response of proficiency (Hunt, 1982).

The implications of this research for guidance and counselling activities are described as follows. Kindergarten teacher acted as a coach needed to have the ability both in terms of attitude and guiding skills. Daradjat (1982: 45) suggests some attitudes that show the meaning of the guidance include: (1) create and develop a sense of hearty and friendly in 
order to create a good relationship, (2) accept children seriously, (3) know the children's feelings and then reflect their feeling, (4) forgive the children, (5) continue to respect the child, and (6) give freedom to the child.

Developing basic language abilities of children, teachers in the kindergarten should master a variety of teaching methods. This teaching method indeed packaged with playing activities, storytelling, and singing. According to Piaget (1951), as mentioned in Christie (1982), games are classified into different categories responding to each stage of cognitive development: practical game, dominates the stage of sensory-motor (from birth to 2 years), symbolic games, stands out during the pre-operational stage (ages 2-7 years), and the game by using rules, stands out during the concrete operational stage (ages 7-11 years). Furthermore, Mustafa states about the importance of socio-dramas games for children of kindergarten. Socio-dramas game is important especially to develop the social skills of children as language learning, such as developing the skills symbolic thinking, abstract, natural social skills that according to the cognitive operations in the language behaviour in today's societies. According to Garvey (1990) and Farver (1992) in Mustafa (2001: 2) socio-dramas game has two essential elements: laid down rules (role-taking) and verbal communication. In the socio-dramas game, the children try to communicate and integrate their daily habits or knowledge that has formed in their social environment or knowledge to his friend.

In order to create a good language environment for kindergarten children, Getswicki (1995), in Solehuddin (2001: 6), suggests the need for some of the following components:

1) Conversation. Educators provide sample opportunity for children to have real conversations, so that they provide the children with the experience about oral communication and thinking.

2) Acceptance. Educators accept the conditions and the development of language skills of children. Correcting children's language mistakes should not be done by blaming them, but by giving the correct example that can hamper the children's motivation.

3) Experience. Educators provide direct experiences through play and communication.

4) Children's Literature. Educators provide opportunities for children to learn and understand more about why people read and get pleasure with books.
5) Other media as extensions of reading material. Educators provide opportunities for children to connect what has been read with their lives. In this case, educators provide materials and activities that allow the children to continue processing their understanding of the contents of the book that has been read.

\section{CONCLUSIONS}

The results showed that the children had enough proficiency to implement the basic language skills i.e. listening, speaking, reading, and writing. The teachers could develop a basic proficiency in children by paying attention to the characteristics of the development of each children, knowing the children's personal data and family, knowing the language used in the family, varying the teaching methods such as storytelling, language games, puppetry, conversing, discussion, dramatization, pronounce poetry, role playing, and field trips, and then choosing a theme that fits in the children's world. Those things must be integrated with the guiding activities in the implementation process of learning in kindergarten.

\section{REFERENCES}

Agustin, M. (2012). Pengaruh Pembelajaran dengan Menggunakan Permainan Tradisional Terhadap Perkembangan Kecerdasan Jamak Anak. Laporan Hasil Penelitian UPI (tidak diterbitkan)

Darajat, Z. (1982). Perawatan Jiwa Anak, Jakarta: Bulan Bintang.

Fisher, B. (1998). Joyful Learning in Kindergarten, Rev, Ed, Portsmouth: Heinemann.

Hall, N. (1987) The Emergence of Literacy, Portsmouth: Heinemann Educational Books, Inc.

Halliday, M.A.K. (1975). Explorations in the Functions of Language. London: Edward Arnold.

Makmun, A.S, (1994), Psikologi Kependidikan, Bandung: PT. Remaja Rosdakarya.

Musthafa, B. (2001). musthafa@indo.net.id.

Otto, B. (2015). Perkembangan Bahasa Pada AnakUsia Dini. Edisi Ketiga. Jakarta: KencanaPrenada Media Group.

Rachmat, J. (1986). Psikologi Komunikasi. Bandung: RemajaKarya CV.

Solehuddin. (2001). Membaca, Menulis, dan Berhitung di Taman Kanak-kanak. Makalah PPB FIP UPI Bandung. 